\title{
Islamic Culture and Western Civilization: The Prospects of Coexistence in the Thought of Alija Izetbegović
}

\author{
Dr. Muhammad Akram \\ Assistant Professor, Department of Comparative Religion, \\ International Islamic University, Islamabad, Pakistan \\ Email: $\underline{\text { m.akram@iiu.edu.pk }}$ \\ Usman Ali Sheikh \\ Teaching/Research Associate, Islamic Research Institute, \\ International Islamic University, Islamabad, Pakistan \\ Email: usman.sheikh@iiu.edu.pk
}

\begin{abstract}
:
Alija Ali Izetbegović (1925-2003) is one of the outstanding Muslim thinkers in recent history who have re-conceptualized the Islamic worldview and ethos in the context of the contemporary world on the one hand and critically reflected upon the modern Western civilization, on the other. Izetbegovic conceives Islam as a system representing a middle path between Christian spiritualism and materialism of modern civilization. However, like any profound philosophical system, his thought requires exposition and interpretation, which the present paper ventures to undertake. Specifically, the paper inquires whether and how far his vision of Islam facilitates coexistence between Muslims and the others, especially regarding the Muslims living in Western societies. The query is crucial because some writers have accused Izetbegovic of being a fundamentalist who pursued an agenda of monolithic Islamic culture with little room for meaningful participation of nonMuslims. The paper concludes that contrary to such negative renderings of his thought, Izetbegović was a thinker with a vast intellectual spectrum and an open outlook. Some of his peculiar notions can be conducive to the coexistence between Muslims and other European communities as well as Islamic culture and Western civilization.
\end{abstract}

Keywords: Islam, materialism, spiritualism, Islamic culture, Western civilization, Muslims in the West, Alija Izetbegović, Bosnia and Herzegovina, fundamentalism, coexistence.

\section{Introduction}

Alija Ali Izetbegović (1925-2003) was the first president of the Republic of Bosnia and Herzegovina (1992-1996) and one of the most 
DOI: 10.33195 /iournal.v4i01.269

eminent leaders in the history of Bosnian Muslims. However, his political eminence often overshadows his career as a Muslim thinker and sociopolitical philosopher. Undoubtedly, he was one of the outstanding Muslim thinkers of the twentieth century. According to one account, his contribution to Muslim thought in the modern world resonates with Muhammad Iqbal (1877-1938) in the East. ${ }^{1}$ A similarity between Izetbegović and Iqbal is that both of them critically reflected upon modern Western civilization, on the one hand, and both re-conceptualized the Islamic worldview and ethos in the context of the modern world, on the other. It is also interesting to note that Iqbal was primarily a poet and philosopher. He did not directly assume the role of a political leader but had envisioned an independent Islamic state in India, which eventually came into being in the form of Pakistan. Izetbegović, on the other hand, was an intellectual and a politician who himself led his community to its destiny of the independent state of Bosnia and Herzegovina.

Like any profound philosophical system, his categorization and analysis of the competing worldviews and his particular conceptualization of the Islamic order of existence allow multiple interpretations. One of his works, The Islamic Declaration: A Programme for the Islamization of Muslims and the Muslim Peoples, advocates for the establishment of an authentic 'Islamic order' in the Muslim countries and unity among different Muslim communities throughout the world. Some scholars have opined that such calling for the establishment of an Islamic order means that he was pursuing a kind of Islamism and establishing a monolithic Islamic society in which there would be little room for meaningful political participation of non-Muslims. ${ }^{2}$ The way he is perceived and received by some Islamist circles can also add some weight to this argument. For instance, the Urdu translation of his book Islam between East and West has appeared in Pakistan with a slightly changed title Isläm aur Mashriq-o-Maghrib kī Tehzībi Kashmakash (Islam and the Tussle of Civilization between East and West), ${ }^{3}$ which has been published by a publishing house associated with Jamā'at-e-Islāmī.

Against this backdrop, we aim to exposit Izetbegović's interpretation of Islam by looking into his significant works and with the help of some secondary materials on his intellectual legacy and political career. More precisely, the exposition attends to the following questions:

a) Was he a fundamentalist as some of his critics have accused him?

b) Does his vision of Islam support peaceful coexistence between Muslims and others?

c) Finally, can the Islamic culture and Western civilization come to common terms in the light of his thought? 


\section{Izetbegović's Intellectual Career and Its Reception}

Alija 'Ali Izetbegović was born on 8th August 1925 in Bosanski Šamac, a town in northern Bosnia, in a middle-class Bosnian family. ${ }^{4} \mathrm{He}$ had a religious upbringing; in particular, he remembers his mother as a pious woman who would wake him up for fajr, the pre-dawn prayer. ${ }^{5}$ Izetbegović grew up in a world reverberating with such ideologies as nationalism, capitalism, fascism, communism, socialism, pan-Islamism, etc. He recalls that, in his youth, when he was around 15 years old, he began to doubt his faith for a brief period ("a year or two") under the influence of communist and atheistic writings. During the later years of his youth, he read major works of European philosophy and was significantly influenced by Bergson's Creative Evolution, Kant's Critique of Pure Reason, and Spengler's Decline of the West. ${ }^{6}$

In the early 1940s, Izetbegovic became involved with the "Young Muslims," an organization that consisted principally of Bosnian Muslim students who were critical of fascism and communism on the one hand and ritualistic Islam, represented by the traditional 'ulama, on the other. Contrary to the views of the traditional "ulamā, who largely confined Islam to rituals, the "Young Muslims" saw an active role of Islam in politics and society. The Yugoslavian authorities arrested Izetbegović in 1946 for his association with the "Young Muslims." After his release in 1949 , he began studying agronomy but transferred to the law faculty later on in 1954, graduating finally in $1956 .^{7}$

In 1970, Izetbegović published The Islamic Declaration, for which the communist regime of Yugoslavia trialed him in 1983. He was sentenced to fourteen years in prison but was released at the end of 1988. After his prison release, he founded a political party, "Party of Democratic Action" (SDA), in $1990 .{ }^{8} \mathrm{He}$ initially received world-wide attention when ethnic and religious fault lines in the heterogeneous Yugoslavian state resulted in its disintegration into smaller independent countries during the early 1990s, after the collapse of the communist regime. Bosnia and Herzegovina was one such state which declared independence in 1992, and of which Izetbegovic became the first president. ${ }^{9}$ The transition, however, was far from being smooth and peaceful. Wars broke out between Croats, Serbs, and Bosnian Muslims. It was Izetbegović who was mainly leading the Bosnian Muslim community during these times of political upheaval and turmoil.

In terms of intellectual contribution and activism, Izetbegović's life passed through three main phases. ${ }^{10}$ First, the phase of discovery and analysis, during which he had, in part, written Islam between East and West in his early twenties. According to Izetbegović's autobiographical notes, he had penned down the preliminary manuscript of the book just 
DOI: $10.33195 /$ iournal.v4i01.269

before his imprisonment in 1946. However, it remained concealed for over two decades as her sister hid it under the beams in their house's attic when he was arrested. When Izetbegović found it later, he added new data and rewrote the text. The book was eventually published in 1984 by an American publisher when Izetbegović was in prison. ${ }^{11}$

The second juncture of his life, which started in the late 1960s, was of intense activism. During this phase, two of his most important works were published: Islam between East and West and The Islamic Declaration. The latter was initially published in 1970, but it primarily caught the world's attention when Izetbegović was put on trial in $1983 .{ }^{12}$ This phase culminated in the infamous Sarajevo Trial and his subsequent imprisonment.

Finally, the phase of reflection, which began around 1990, during which he was relating his previous and present assertions in his speeches and interviews as a national leader of Bosnia and Herzegovina. His statesmanship came to the fore during this phase in which he founded a political party and served as the President and war-time leader of Bosnia and Herzegovina. At the end of this phase, he published his Autobiographical Notes, which offers valuable insights into this last period of his life.

Izetbegović's oeuvre consists of more than half a dozen books, speeches, lectures, and interviews. ${ }^{13}$ However, his thought about Islam is primarily, though not exclusively, encapsulated in such works as Islam between East and West and The Islamic Declaration. In Islam between East and West, his magnum opus, he presents Islam as the most plausible alternative among the competing ideologies of contemporary times. In this book, Izetbegović contends that "there are only three integral views of the world: the religious, the materialist and the Islamic." Here Islam is represented as a synthesis or a third way between the opposing religious and materialistic tendencies in the world. ${ }^{14}$

His second most important work is titled The Islamic Declaration: A Programme for the Islamization of Muslims and the Muslim Peoples. As the title itself indicates, this work is programmatic. It advocates establishing an authentic 'Islamic order' in the Muslim countries and unity among different Muslim communities throughout the world. Other books that provide clues to his thought include Inescapable Questions: Autobiographical Notes and Izetbegović of Bosnia and Herzegovina: Notes from Prison, 1983-1988. Both of these books pertain to collections of his diary notes and short pieces of reflections.

Izetbegović's body of work has received attention from scholarly and non-scholarly quarters alike. Not surprisingly, his works have been received eagerly in the Muslim world. For instance, a Pakistani scholar 
Muhammad al-Ghazali views him as an "outstanding Islamic thinker" and "a master theoretician of its ideology in the contemporary world." He includes him in the list of luminaries of Muslim scholarly tradition, which comprises of such scholars as Imām al-Ghazali, Ibn Taymiyyah, al-Razi, Ibn al-Arabi, etc. Commenting on Islam between East and West, he contends that in this work, Izetbegovic has primarily come up with a critique of the whole modern Western civilization. He writes: "[T]here has not so far come to the fore any seminal critique of the Western thought as a whole which could also set a new doctrinal trend for an authentic contemporary Islamic discourse. Such seminal scrutiny of the Western ideas in their historical perspective has, to our knowledge, been singlehandedly and quite successfully attempted by "Alija Izetbegović."15

Offering a different reading of the same work, Amina Selimovic, a Bosnian scholar, in her Master's thesis presented at the University of Oslo, opines that Izetbegović's Islam between East and West is not a critique of the Western way of thinking. Instead, it mainly criticizes the narrow understanding of Islam, which reduces it to a religion preoccupied with the next world. ${ }^{16}$

Alija Izetbegović's works have also been subjected to criticism, often in media campaigns and sometimes as critical scholarly inquiry. As hinted above, Izetbegović was arrested by the Yugoslav government for allegedly creating a counter-revolutionary group against the communist regime of the time, whose program was purportedly based on The Islamic Declaration. ${ }^{17}$ In the wake of Yugoslavia's disintegration and during the war following it, The Islamic Declaration was again used by some Serbian scholars and press, and parts of Western media to portray Izetbegović as an Islamic fundamentalist who was attempting to establish an Islamic state in Europe where the religious freedom of others would be compromised. ${ }^{18}$

In a monograph written from a strategic and policy perspective ${ }^{19}$, Leslie S. Lebl views the growth of Islamism in Bosnia and Herzegovina as particularly problematic in the wake of the economic and ethnic problems that it faces. Distinguishing between several types of Islamists in Bosnia and Herzegovina, she links Izetbegović and his political successors with the Muslim Brotherhood. She argues that Islamism first appeared in Bosnia in 1941 when Izetbegović, along with others, formed the "Young Muslims," which was patterned after the Muslim Brotherhood. According to her, Izetbegović has elaborated his Islamist ideology in his political manifesto, The Islamic Declaration. Referring to Izetbegović's views in The Islamic Declaration regarding non-Muslims living in an Islamic state, she writes: "The Declaration's message is simple: Muslims should play by the democratic rules until they are strong enough to impose an Islamic state. Once there is an Islamic state, non-Muslims may remain, but only in 
a subordinate status. If Christians abandoned their religious organization, Izetbegović was prepared to offer the "understanding and cooperation."'20

In a similar vein, albeit in a scholarly tone, Dražen Pehar has criticized not only Izetbegović's conception of Islam but also his leadership after the disintegration of Yugoslavia. Pehar accuses him of being equally responsible, or co-responsible, for the beginning of the war in Bosnia. He, being the representative of the weakest party in the conflict, embraced the option of armed conflict. He contends that Izetbegović's decision-making in those turbulent times rested partly on his political philosophy, of which his idea of Islam forms a crucial part. Pehar hesitates to use the word "fundamentalism" while referring to Izetbegović because of its ideological undertones but still finds fundamentalist elements in his conception of Islam. He further asserts that Izetbegović's Islam between East and West asserts the superiority of Islam over all the intellectual and spiritual alternates, which makes him an "Islamic supremacist." For him, this kind of faith in one's superiority motivates a demeaning attitude towards the others, creating conflict between the representatives of "the superior religion" and the other religions. Besides, this kind of faith could lead the representative of superior religion to think "that he has already won, or that the existence of the representative of the 'inferior' religions is not as meaningful as his own." 21

\section{Izetbegović's Vision of Islam}

Izetbegović's vision of Islam has two levels. Firstly, he advocates for a particular integrated view of Islam in the context of two rival approaches to Islam in the contemporary world, which is primarily meant for Muslim societies. Secondly, his conception of Islam as an alternative worldview for the whole of humanity. At the first level, Izetbegović looks at Islam from within the confines of Islamic thought and practice in modern times. In contrast, at the second level, he looks at Islam from without, against the backdrop of the competing worldviews in modern civilization. Allowing some generalization, in The Islamic Declaration, one finds Izetbegović's understanding of Islam from within, while his vision of Islam from without culminates in Islam between East and West. ${ }^{22}$

Let us begin with how Izetbegović envisions Islam from within, especially as epitomized in The Islamic Declaration. At the very outset of this document, he writes that it is not a prescribed reading for those who are not already Muslims. The sole purpose of this document is to help Muslims understand the consequences of their belief and allegiance. He further clarifies the purpose of this document, which is to show the path which leads to the organization of various spheres of life, individual, familial, and societal, through the renewal of Islamic religious thought. ${ }^{23}$ $\mathrm{He}$ embarks on the task of sketching out this renewal of the Islamic 
thought by leveling stark criticism of the conservative and modernist approaches to Islam, which he thinks have negatively affected the Muslim societies. According to him, conservatives stick to outdated forms, while modernists want to adopt someone else's forms. Izetbegović vehemently rejects both of these approaches, saying that while the former attitude drags Islam back into the past, the latter pushes toward the future, albeit to an unknown future. Both of them perceive Islam as a "religion" in the European sense of the word, which denotes a sort of spiritualism at the cost of rationality and which mainly relates to the private sphere. ${ }^{24}$

Izetbegović maintains that there has emerged a class of self-styled clergy in the Islamic world against the clear teachings of Islam, which do not recognize any mediators between man and God. It is this class that represents the conservative interpretation of Islam today. They have reserved the right of interpretation of the Qur'an exclusively for themselves.

As clergy they are theologians, as theologians they are invariably dogmatic and, as the faith has been given once and for all, in their opinion it has also been interpreted once for all. ... Any further remodeling of the Sharia as law, in the sense of applying Qur'anic principles to new situations which continue to emerge from world developments, is equated with an attack on the integrity of the faith. ${ }^{25}$

He thinks that such theologians are the wrong people in the wrong place. They can neither withstand the new challenges nor materialize the Muslim communities' emerging opportunities. In short, they cannot guide Muslims for the challenges of the contemporary world.

On the other hand, there are progressive, modernist, or westernized Muslims who are holding political power in most of the Muslim societies. They are the blind imitators of everything that is modern and which is coming from the West. They are usually schooled in European educational institutions and develop a sense of inferiority about their own culture, which results in devastating impacts on the local ideas, customs, and convictions. ${ }^{26}$ The main problem with this group is that even their understanding of modernism remains superfluous. Modernity for them revolves around night-clubs, godlessness, and fashion. They fail to see that the Western world's real power lies in qualities like great diligence and ethics of work, the pursuit of rational knowledge, persistence, and its people's sense of responsibility. ${ }^{27}$

Izetbegović presents a general theory about the history of religions. According to him, every religion has two sides. "As a science, it is a revelation; as practice, it is the work of men. God reveals faith, and people apply it. All that is in it that is great and sublime is of God; all that is 
wrong and unworthy is of men."28 Applying this understanding of the phenomenon of religion to Islam, he concludes that the Muslim world is passing through a dark night of its history, which he sees as a result of the darkening of the hearts. ${ }^{29}$

For Izetbegović, the true spirit of Islam needs to be rediscovered against these odds by drawing on the original teachings of the Qur'an and making them relevant to the contemporary situation. According to him, one main reason behind the backwardness, corruption, poverty, and ignorance in Muslim societies is their distance from the Qur'an's teachings. He laments that the Qur'an is ritually recited so many times without understanding it. In his own words: "An extensive and pedantic science has been established on how the Qur'an should be pronounced so as to avoid the issue of how to practice it in daily life." 30

After taking stock of the existing situation and identifying problems of the Muslim world in the first part of The Islamic Declaration, Izetbegović presents his unique vision of the 'Islamic Order' in the second part of this document. Here he begins with this task by outlining some principles. He maintains that while there are a few fundamental principles in Islam that never change, there are essentially no fixed Islamic economic, social, and political structures handed down to Muslims once and for all, which do not change according to the time's needs. Every generation would have to take onto itself the responsibility to develop such structures which meet the requirement of the historical situation. ${ }^{31}$

Then, he details the essential aspects of his vision of an Islamic order." ${ }^{32} \mathrm{He}$ maintains that "Islam is religion, but is at the same time a philosophy, a moral system, an order, a style, an atmosphere - in a word, an integrated way of life." 33 He finds Islam to be different from the other philosophies and religions in that it requires that "man must live an interior and exterior, moral and social, spiritual and physical life." 34 Thus, for all these diverse dimensions to be taken care of, both an Islamic society and Islamic governance are needed to establish the Islamic order. This order is based on brotherhood and unity of Muslims, and equality of people. In the Islamic order, there is no possibility of differentiation between people based on class, color, or race, save the difference of spiritual and ethical values that one practically demonstrates. ${ }^{35}$

Economically, private property is allowed in this order, albeit not as understood in Roman law. Personal property in Islamic order has one privilege less, the right to abuse, and one obligation more, to use one's wealth for the common good. To avoid exploitation and parasitic lifestyle, Islam forbids interest, and to ensure the distribution of wealth among different social classes, it enjoins the system of obligatory charity (Zakât). 
Politically, the Islamic order stands for republican principles and democracy. It does not recognize the rule of inheritance for political power. The phase of the ideal caliphate during the reign of the first four caliphs of Islam demonstrated the republican principles like the elective head of state and responsibility of the head of state towards people. ${ }^{36}$ Then, the document elaborates on several issues like the status of women, freedom of conscience, dignity of work, justice, the rights of minorities, and relations with other communities. Some topics that relate to the question of peaceful coexistence are discussed below in the next section.

Now, let us move towards the magnum opus of Izetbegović, namely Islam between East and West, which is a more profound and less programmatic text compared to The Islamic Declaration. The scope of this work is also broader, as its intended readership does not seem to be limited to Muslims. According to him, this book pertains to a look at Islam from without, against the backdrop of the broad spectrum of ideas. ${ }^{37}$ The book comprises two main parts. The first part is titled 'Premises,' and it consists of six chapters, while the second part is titled 'Islam: Bipolar Unity.' A short supplement of three pages named 'Submission to God' follows the two main parts. In the first part of the book, Izetbegovic propounds his central thesis of the essential dualism of matter and spirit, which he finds in all philosophical and religious systems of the world. In contrast, in the cluster of five chapters which make up the second part, he presents Islam as the principle which overcomes this dualism in what he calls the bipolar unity.

A note regarding the peculiar usage of the term Islam seems in order here. Firstly, Izetbegović distinguishes between religion and Islam. For him, religion has acquired a narrow connotation in European history, and it essentially relates to the spiritual aspect of the man at the cost of material one. Islam, in turn, simultaneously refers to man's spiritual and material existence. He makes another clarification that in this book, Islam does not mean a set of regulations rather a principle that synthesizes contrasting elements. So Islam in this book is presented as a method rather than a readymade solution. ${ }^{38}$

Interestingly, Izetbegović contends that there are only three integral worldviews, the religious, materialistic, and the Islamic. ${ }^{39} \mathrm{He}$ elaborates on three worldviews in the following words: "They reflect three elemental possibilities - conscience, nature and man, each of them manifesting itself as Christianity, Materialism and Islam." ${ }^{40}$ He illustrates various manifestations of these three worldviews by using a table with three columns, ' $\mathrm{R}$ ' for religion, ' $I$ ' for Islam and ' $M$ ' for materialism. In the ' $R$ ' column, one finds spirit, conscience, soul, organic, quality, religion, art, ethics, consciousness, meditation, ideal, sin, drama, creation, 
DOI: $10.33195 /$ iournal.v4i01.269

culture, Jesus, and Christianity. The ' $\mathrm{M}$ ' column includes matter, being, body, mechanic, quantity, science, logic judgments, need, interest, observation, intelligence, experience, power, evolution, progress, civilization, utopia, Moses, and materialism. In the 'I' column, the reader finds man, salah, zakah, mosque, law, shari'a, justice, jihad, jamā'ah, ummah, caliphate, marriage, Muhammad, and Islam.

It is through this schematization that he contrasts an array of conceptual opposites like creation and evolution, spirit and matter, tool and cult, education and meditation, utopia and drama, society and community, and culture and civilization. In this scheme, Christianity is the culmination of religion, which takes as its starting point the existence of spirit; materialism accepts matter only, while Islam simultaneously recognizes spirit and matter. Since man is both spirit and matter, all the problems man is facing are either because of religious denial of man's material needs or materialist negation of the spiritual dimension of man. ${ }^{41}$

Corresponding to evolution and creation, man has two histories. ${ }^{42}$ One relates to his evolution as an animal through which he has acquired intelligence and skills to use tools, established societies, developed sciences, and built grand civilizations. Man's other history goes back to a stage when God "created" man by giving him moral conscience and freedom of choice between good and bad deeds. This history of man relates to cults, religion, art, and drama. ${ }^{43}$

In the second part, Islam is also seen as having two histories, the history of Islam before the Prophet Muhammad, peace be upon him, and the history of Islam after him. It means that Izetbegović considers the history of Judaism and Christianity as a part of the history of Islam in the broader sense. He views Judaism as essentially materialistic and thisworldly, ${ }^{44}$ and Christianity as fundamentally spiritualistic and the otherworldly. Judaism seeks to establish the Kingdom of God on the Earth, while Christianity idealizes the Kingdom of God in Heaven. These two contrasting outlooks represent the history of Islam before the advent of Prophet Muhammad, peace be upon him. Then, he divides the history of Islam in the narrow sense, that is, after the coming of the Prophet Muhammad, into the Makkan and Madinan phases. In Makkah, Islam remained only a spiritual system, without social order. It is in Madinah that Islam became complete by combining the individual spiritual dimension with social and material principles. ${ }^{45}$ To quote him: "Islam reached its culmination in Madinah. In the cave of Hira, Muhammad was faster, an ascetic, a mystic, a haniff. In Makkah, he was a herald of religious thought - in Madinah, he became a herald of Islamic thought. The message that Muhammad bore was completed and crystallized in Madinah. Here - and not in Makkah — was the 'start and source of the 
DOI: 10.33195 /iournal.v4i01.269

entire Islamic social order." 46 By pointing out the historical and systematic connections between the three Semitic religions, Izetbegović concludes that the kinship of Islam and Christianity is often ignored. ${ }^{47}$

\section{Prospects of Intercommunal Coexistence in Izetbegović's Thought}

Now, let us consider does Izetbegović's vision of Islam support the peaceful coexistence of Muslim communities in European societies. In this connection, a statement of Izetbegović in The Islamic Declaration is often mentioned. He writes: "There can be neither peace nor coexistence between the Islamic religion and non-Islamic social and political intuitions...By claiming the right to order its own world itself, Islam obviously excludes the right or possibility of action on the part of any foreign ideology on that terrain." ${ }^{48}$ This quotation may seem quite conclusive, leaving no space for further discussion on the issue of peaceful coexistence in Izetbegović's vision of Islam. However, reading the passage in its broader context changes the whole picture.

First of all, at another place in the same document, one finds an accommodative statement: "Nothing which can make the world a better place may be rejected out of hand as non-Islamic." 49 Then, one may note here that, as the author himself states at the very outset, The Islamic Declaration was intended only for Muslim leadership, and the whole program of 'Islamic order' presented in the document is meant for the societies with Muslim majorities. ${ }^{50}$ Izetbegović would not support establishing the 'Islamic order' in the societies where the Muslim community is not a majority. He also clearly states that non-Muslim minorities living in the Islamic state enjoy full religious freedom and protection. ${ }^{51}$ What is even more important is the fact that according to Izetbegović, "Muslim minorities within a non-Islamic community, provided they are guaranteed freedom to practice their religion, to live and develop normally, are loyal and must fulfil [sic.] all their commitments to that community, except those which harm Islam and Muslims." 52 Thus, according to Noel Malcolm, "some of the arguments in this treatise which have been described as 'fundamentalism' are simple statements of orthodox belief with which many sincere Muslims would agree." 53

Izetbegović sketches out a set of principles for the relationship between Islam and other communities. He thinks that these relations are based on the principles of freedom of religion, strong and active defense, a ban on wars of aggression and crime, cooperation and acquaintanceship among nations, respect for obligations and agreements undertaken, and mutuality and reciprocity. ${ }^{54}$ In turn, he relates all these principles with the relevant verses of the Qur'an. 
DOI: 10.33195 /iournal.v4i01.269

Apart from these theoretical principles, he welcomes the declaration passed during the Second Vatican Council about the constructive relationship of Christianity with other religions. In this context, he writes: "We applaud the new tendencies in the church declared by the latest Vatican Council because we consider that to a certain extent they come closer to the original tenets of Christianity. If Christians wish so, the future may offer an example of understanding and cooperation between the two great religions for the well-being of people and mankind, just as the past has been the battlefield of their senseless intolerance and strife." 55 Along the same line, though he denounces Zionism, he states that Muslims do not have problems with other Jews. He also speaks of the possibility of shared everyday life between Jews and Muslims on the Palestinian soil. ${ }^{56}$

Indeed, Izetbegović was concerned, as a committed Muslim, with the Islamic revival and establishment of an 'Islamic Order' across the Muslim world, as The Islamic Declaration indicates. However, as hinted above, he deemed the establishment of such an order appropriate for the states with absolute Muslim majorities. Against this background, it seems natural to inquire into Izetbegović's vision for Bosnia as a state where Muslims constituted the largest religious community, albeit not an absolute majority. First, he did not consider Bosnia and Herzegovina an Islamic state, where the program presented in The Islamic Declaration was to be implemented. He envisioned Bosnia and Herzegovina as a multi-cultural, multi-ethnic, and multi-religious democratic state where people from different religions, ethnicities, and political inclinations could live together peacefully.

In this regard, he is remarkably consistent in his views, as is evident from his statements ranging from the periods of pre-independence Yugoslavia as well as war-time and post-war Bosnia and Herzegovina. It is, perhaps, worthwhile to look at some of his statements in this connection. For instance, on the occasion of announcing the foundation of his political party in March 1990, Izetbegović read out a 16 point programmatic statement signed by the founders of the party, which included, among other things, a statement about freedom of religion as a fundamental human right. The statement advocated for "full freedom of action of all religions in Yugoslavia, the full autonomy of their religious communities." Among other rights, the statement also advocated for freedom for building places of worship as per the demands and needs of the religious communities, access to the information media for them, recognition of the major religious festivals as holidays for the relevant religious community, and, if there was a single religion in the majority, then that festival would be recognized as a state holiday. It was suggested 
DOI: 10.33195 /iournal.v4i01.269

in the statement that in the case of Bosnia as a multi-religious republic, these festivals would be two Eids and the Catholic and Orthodox Christmas. ${ }^{57}$

In a similar vein, in a public speech in September 1990, Izetbegović affirmed "Bosnia and Herzegovina as a civil republic ... not Islamic, and not socialist either." ${ }^{58} \mathrm{He}$ reiterated this stance in December 1991, while giving a speech at the first congress of his party, SDA: "Serbia and Croatia are nation-states. Bosnia and Herzegovina is not, and can therefore only be a civil republic. For it is not Serbs, Croats, and Muslims who live in Bosnia and Herzegovina, but a national blend of these peoples, and others too." 59

Izetbegović's standpoint remained the same after Bosnia and Herzegovina declared independence from Yugoslavia and was forced into war with its neighboring states. It was the time when he was continuously accused of creating an Islamic state in the independent Bosnia and Herzegovina. Replying to one such accusation by Franjo Tudjman, ${ }^{60}$ he contended in a TV interview in November 1993 that he had no intention of creating the Islamic Republic in Bosnia. ${ }^{61}$ Perhaps more illuminating in this regard is the speech that he delivered on the independence day of Bosnia and Herzegovina on $1^{\text {st }}$ March 1995: "Our aim is a Bosnia of free people, a Bosnia in which the human being and human rights will be respected. We oppose the concept of mono-national, mono-religious, oneparty parastates ... with our concept of a free democratic Bosnia." ${ }^{62}$

He invokes both the Qur'an and Western democracy when he speaks about religious freedom and tolerance for others. In the backdrop of the killing of two priests in the Bosnian town of Fojnica in December 1993, Izetbegović delivered the following speech on the conduct of soldiers:

Assuming that the murderer was one of us ... his attitude would have been - they destroyed our Old Bridge, let's get back at them ... This way of thinking gets us nowhere ... We have been slaughtered ... our mosques destroyed, but we shall not kill women and children, we shall not destroy churches. We shall not do so, because this is not our way ... we respect others' religions, others' nations, and other political convictions ... when we say that we wish to respect churches and the faith of others, we are not only upholding the finest traditions of European democracy, which the world has slowly groped its way to through the ages, but also directly and literally respecting the precepts of our Holy Book. ${ }^{63}$

Izetbegović kept on stressing the multi-ethnic and multi-religious nature of Bosnia and Herzegovina even after the war ended. In a session of 
the main board of SDA, he emphasized the task to rebuild Bosnia as a multi-religious and multi-national state post-Dayton agreement and how such a state would have a great significance for the whole world:

[T] he circumstances have placed a different task ahead of us: to create a multi-national state ... It is an experiment to create a possibility of a common state for three nations, three religions and three cultures. The success of this experiment will have historical significance not only for us but for the whole world. ${ }^{64}$

It is worthy to note here that his stance about Bosnia as a multireligious and multi-national state stems from his vision of democracy. He believes that God has created people free and equal and with a "certain number of inalienable rights," which no authority has the right to deprive them of. He does not believe in the unlimited power of the majority, as "the tyranny of the majority is tyranny like any other" and "that the measure for freedom is treatment of the minorities." ${ }^{\prime 65}$ Apart from the rights of religious and national minorities, other core values of democracy, which he stressed time and again, are total equality before the law, freedom of thought, freedom to political activity, and freedom of press/media. ${ }^{66} \mathrm{He}$ did not allow censorship even during the war-time. ${ }^{67}$

A criticism alluded to in a previous section is regarding Izetbegović's concept of Islam as envisioned in Islam between East and West, where Islam is presented as superior to all other intellectual and spiritual alternatives. As Izetbegović himself hints, this criticism stems from a literal (or as he calls it, "line by line") reading of his book and not the vision outlined in it. He clarifies in his autobiographical notes that he gave several concepts, like Judaism, Christianity, and Islam, a metaphorical rather than a conventional meaning. Islam, in this context, is a "major metaphor for the 'third way' for every form of life, with a formula that fulfills the human person." 68

What is explicit in his autobiographical notes is embedded in his Islam between East and West. The chapter on "The Third Way Outside Islam" perhaps illustrates this fact, where Izetbegović finds tendencies of "Islam" in other parts of the world, especially in England and, to some extent, the Anglo-Saxon world in general. He argues that England's experience should be considered differently from Continental Europe, where Religion and Science and Church and State have historically stood at different poles with no middle ground between them. For him, the emergence of England and Anglo-Saxon spirit in the West is comparable to the emergence of Islam in the East. ${ }^{69}$

Izetbegović considers Roger Bacon as the best example of the dualism of the English way of life, who never attempted to "reduce the 
scientific or religious outlooks at the other's expense" and "established a balance between them." He also cites examples of John Locke, an empiricist, and Thomas Hobbes, a positivist and a materialist, who, despite their scientific outlook, retained their religious beliefs. In a similar vein, Izetbegović refers to American pragmatism as a typical example of AngloSaxon philosophy, which accepts both science and religion, provided they prove their practical worth. ${ }^{70}$

Izetbegović also identifies tendencies of this "third way" in other parts of the western world; but cautions that unlike the Anglo-Saxon world, where they also exist at the level of theory, in those parts of the world, they arose only from practical necessities. In this regard, he mentions the dialogue between the Catholics and the Marxists-initiated in the 1960s in historically Catholic countries - where both acknowledged the need to change their attitudes toward each other. Similarly, in countries with a Protestant majority, Izetbegović sees the rise of social democracy, a compromise between liberalism and social intervention, and between the European Christian tradition and Marxism, as a manifestation of the third or middle way. ${ }^{71}$

It is also noteworthy how vehemently Izetbegović rejects dogmatism and the narrow-mindedness of the conservative class of Muslim clergy, which often hinders the necessary adjustments in any new situation. He maintains that only some principles of Islam are permanent and that there are no essentially permanent Islamic social, political, and economic orders readily available. It is the historical and cultural situation that would determine which type of institutions Muslims would establish or with which existing structures they would make adjustments to. This framework certainly opens up possibilities of flexibility, change, and needed adjustments in the challenging new cultural spaces. Thus, there is no wonder that in the introduction to Islam between East and West, Dr. S. Balic writes:

Islam offers its adherents many ways of coping with life in secularized society. Mention may be made, for example, of the absence of sacraments, of priesthood and of baptism, the civil nature of marriage, the natural approach to sexuality, the rejection of the idea of excommunication, the positive attitude to knowledge and scientific research, the relative toleration of mixed marriages, and the long-standing readiness for dialogue with the monotheistic religions. ${ }^{72}$

Finally, it is maintained that there are some other concepts of Izetbegović that can facilitate coexistence between Muslims and the other European communities. The way he conceives Islam as the middle path between the bipolarities like culture and civilization, community and 
DOI: $10.33195 /$ iournal.v4i01.269

society, education and meditation, drama and utopia makes his thought integrative and accommodative.

For instance, his peculiar way of distinguishing between culture and civilization can open up a possibility for multiculturalism from the very definition of culture. Culture tends towards individualization, participation, freedom of the will, and impromptu performance, while civilization provides the needed material space for culture. Thus, Western civilization can serve as a cradle for multiculturalism owing to what Izetbegović would call its material and scientific advancement and JudaicChristian religious foundations. As hinted above, Izetbegović endorsed the case of Anglo Saxon world, where a synthesis of material and spiritual aspects has taken place outside Islam. ${ }^{73}$

The same applies to his distinction between community and society. For him, society is mere collectiveness, while community refers to sharing and belonging. The most important in this connection is his assertion that practically every community assumes the character of society and vice versa. ${ }^{74}$ This interchangeability of community and society can provide the framework for the peaceful coexistence of various communities within a society.

\section{Conclusion}

Izetbegović's vision of Islam is open to multiple interpretations. There is no denying that he was a committed Muslim who viewed Islam as a complete code of individual and collective life, which makes some people interpret his thought along the narrow religio-ideological lines. Some even accused him of being a fundamentalist. However, the fact is that he was a thinker with a broad intellectual horizon and profound philosophical outlook. He envisioned Islam not as a "religion" with the narrow connotation that this category has acquired in the modern West; instead, he views it as a middle path between the materialistic and spiritual worldviews. For him, Islam is an integrative worldview that can cope with the inner contradictions of modern civilization. He even sees glimpses of "Islam," as he understands it, in some non-Muslim societies, especially in the Anglo-Saxon world. These features of his thought make its openended and inclusive rendering more plausible. Indeed, his unique vision of Islam as a flexible, integrative, and extendable system can open up fresh prospects of coexistence between Muslims and others in general and between the Islamic culture and modern Western civilization in particular.

The political career of Izetbegovic also supports the above interpretation of his thought. His role had been vital in bringing the Bosnian war to a peaceful solution, which resulted in the ethnically and religiously diverse state of Bosnia and Herzegovina. Thus, he practically 
demonstrated how Muslims could coexist with ethnic and religious others and form common political institutions and social structures.

\section{References \& Notes}

${ }^{1}$ Dzemaludin Latic, "Iqbal from the West: Alija," trans. Sadina Gagula-Paladic in Balkanlarda Gelecek Tasavvuru: Kültür, Siyaset, Örgütlenmeve Işsbirliği Alanları, eds. Ümmühan Özkan and Selda Şen (Turkey: İnsani Yardım Vakfi, 2008), 93.

${ }^{2}$ John R. Schindler, Unholy Terror: Bosnia, Al-Qa'ida, and the Rise of Global Jihad (Minneapolis: Zenith Press, 2007), 48-49.

${ }^{3}$ Alija Ali Izetbegović, Islām aur Mashriq-o-Maghrib kī Tehzībī Kashmakash [Islam and the Tussle of Civilization between East and West], trans. Muhammad Ayyūb Munīr (Lahore: Idārah-e Ma‘ārif-e Islāmī, 1997).

${ }^{4}$ Enes Karić, “Alija Izetbegović (1925-2003),” Islamic Studies 43, no. 1 (2004): 181.

${ }^{5}$ Alija Izetbegović, Inescapable Questions: Autobiographical Notes, trans. Saba

Rissaluddin \& Jasmina Izetbegović (Leicester: The Islamic Foundation, 2003), 12.

${ }^{6}$ Karić, “Alija Izetbegović,”, 182-183; Izetbegović, Inescapable Questions, 13-14.

${ }^{7}$ Karić, “Alija Izetbegović,”, 183-185; Izetbegović, Inescapable Questions, 58.

${ }^{8}$ Karić, “Alija Izetbegović," ,185-186.

${ }^{9}$ Sumantra Bose, Contested Lands: Israel-Palestine, Kashmir, Bosnia, Cyprus, and Sri

Lanka (Cambridge, Massachusetts \& London: Harvard University Press, 2007), 124.

${ }^{10}$ M. A. Sherif, Why an Islamic State - The Life Projects of Two Great European

Muslims (Selangor: Islamic Book Trust, 2009), 3-4.

${ }^{11}$ Izetbegović, Inescapable Questions, 26.

${ }^{12}$ Ibid, 25-26.

${ }^{13}$ Karić, “Alija Izetbegović ,”,186.

${ }^{14}$ Alija Ali Izetbegović, Islam between East and West (Indianapolis: American Trust Publications, 1984), iii; Izetbegović, Inescapable Questions, 26-27; Alija Izetbegović, Izetbegović of Bosnia and Herzegovina: Notes from Prison, 1983-1988 (Westport, CT: Praeger, 2002), 105-106.

${ }^{15}$ Muhammad al-Ghazali, "Islam between East and West: The Magnum Opus of Alija Izetbegović," Islamic Studies 36, no. 2, 3 (1997): 524, 526, 531.

${ }^{16}$ Amina Selimovic, "Dualism of the World: An Analysis of Islam between East and West, the Magnum Opus of Alija Izetbegović, with the Speech-Act Approach" (MA diss., University of Oslo, 2009), 9.

${ }^{17}$ For the details of the charges and Izetbegović's responses, see: Anto Knežević, "Alija Izetbegović's "Islamic Declaration": Its Substance and Its Western Reception," Islamic Studies 36, no. 2, 3 (1997): 497-501.

${ }^{18}$ For the details of Serbian and Western criticism of Izetbegović, see: Ibid, 502-509.

${ }^{19}$ The monograph is published by the Strategic Studies Institute (SSI), which is a part of U.S. Army War College.

${ }^{20}$ Leslie S. Lebl, Islamism and Security in Bosnia-Herzegovina (Carlisle, PA: Strategic Studies Institute and U.S. Army War College Press, 2004), 2-6, 21, 31.

${ }^{21}$ Dražen Pehar, Alija Izetbegović and the War in Bosnia-Herzegovina (Mostar: HKD Napredak, 2011), 116-119, 136-138, 152-153. 
${ }^{22}$ Izetbegović, Islam between East and West, iii.

${ }^{23}$ Izetbegović, The Islamic Declaration, 3-5.

24 Ibid, 8.

${ }^{25}$ Ibid, 9.

${ }^{26}$ Knežević, “Alija Izetbegović’s "Islamic Declaration,” 484.

${ }^{27}$ Izetbegović, The Islamic Declaration, 11.

28 Izetbegović, Izetbegović of Bosnia and Herzegovina, 29

${ }^{29}$ Izetbegović, The Islamic Declaration, 18.

${ }^{30}$ Ibid, 20.

${ }^{31}$ Ibid, 32.

${ }^{32}$ Knežević, “Alija Izetbegović's “Islamic Declaration,” 485-488.

${ }^{33}$ Izetbegović, The Islamic Declaration, 26.

${ }^{34}$ Ibid, 29.

${ }^{35}$ Ibid, 26, 34-36.

${ }^{36}$ Ibid, 37-39.

${ }^{37}$ Izetbegović, Islam between East and West, iii.

${ }^{38}$ Ibid, 1-5.

${ }^{39}$ Izetbegović, Izetbegović of Bosnia and Herzegovina, 105-106.

${ }^{40}$ Izetbegović, Islam between East and West, 1.

${ }^{41}$ Ibid.

${ }^{42}$ Izetbegović considers the viewpoints of both science and religion about the origin of man as right. See for his detailed explanation: Izetbegović, Izetbegović of Bosnia and Herzegovina, 153.

${ }^{43}$ Izetbegović, Islam between East and West, 9-37.

${ }^{44}$ Izetbegovic gives an interesting explanation about the materialistic tendencies in Jewish history in his Notes from Prison; for details see: Izetbegović, Izetbegović of Bosnia and Herzegovina, 119.

${ }^{45}$ Izetbegović, Islam between East and West, 146-151.

46 Ibid, 151-152.

${ }^{47}$ Ibid, 157.

${ }^{48}$ Izetbegović, The Islamic Declaration, 30.

${ }^{49}$ Ibid, 31.

${ }^{50}$ Ibid, 3.

${ }^{51}$ Knežević, “Alija Izetbegović’s "Islamic Declaration,” 506.

${ }^{52}$ Izetbegović, The Islamic Declaration, 50.

${ }^{53}$ Noel Malcolm, Bonia: A Short History (London: Pan Macmillan, 1994), 220.

${ }^{54}$ Izetbegović, The Islamic Declaration, 50.

${ }^{55}$ Ibid, 68.

${ }^{56}$ Ibid, 68-69.

${ }^{57}$ Izetbegović, Inescapable Questions, 70.

58 Ibid, 81.

${ }^{59}$ Ibid, 105.

${ }^{60}$ Franjo Tudjman was a historian and became the first president of Croatia when it declared independence from Yugoslavia. Like Izetbegović, he was also imprisoned by Yugoslav communist government for his political views. See for details: Robert 
Stallaerts, Historical Dictionary of Croatia (Plymouth: The Scarecrow Press, 2010), 32124.

${ }^{61}$ Izetbegović, Inescapable Questions, 172-73.

62 Ibid, 210.

${ }^{63}$ Ibid, 173-174.

${ }^{64}$ Ibid, 406.

${ }^{65}$ Vincent J. Cornell, "Reasons Public and Divine: Liberal Democracy, Shari'a

Fundamentalism, and the Epistemological Crisis of Islam," in Rethinking Islamic Studies:

From Orientalism to Cosmopolitanism, eds, Carl W. Ernst and Richard C. Martin

(Columbia, South Carolina: University of South Carolina Press, 2010), 23, 46.

${ }^{66}$ Izetbegović, Inescapable Questions, 68, 478, 509, 525-26.

${ }^{67}$ Ibid, 54.

${ }^{68}$ Ibid, 27-28.

${ }^{69}$ Izetbegović, Islam between East and West, 211-212.

${ }^{70}$ Izetbegović provides quite a few examples of Anglo-Saxon intellectuals who exhibited this "middle way" in their thought. For details see Ibid, 212-219.

${ }^{71}$ Ibid, 219-222.

${ }^{72}$ S. Balic, "Introduction" to Islam between East and West, Alija Ali Izetbegović (Indianapolis: American Trust Publications, 1984), vii.

${ }^{73}$ Izetbegović, Islam between East and West, 211-223.

${ }^{74}$ Ibid, 133-135.

\section{Acknowledgment:}

An erlier draft of this paper was presented at the internaitonal workshop titled Localized Islam(s): Practice and Culture in European Context, held on March 20-21, 2014, at the European University Institute, Florence, Italy.

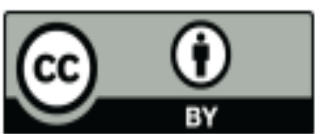

@ 2020 by the author, Licensee University of Chitral, Journal of Religious Studies. This article is an open access article distributed under the terms and conditions of the Creative Commons Attribution (CC BY) (http://creativecommons.org/licenses/by/4.0/). 